\title{
Suppression of the p300-dependent mdm2 negative-feedback loop induces the p53 apoptotic function
}

\author{
Anju Thomas and Eileen White ${ }^{1,2}$ \\ Center for Advanced Biotechnology and Medicine, Cancer Institute of N ew Jersey, Department of Molecular Biology \\ and Biochemistry, Rutgers University, Piscataway, N ew Jersey 08854 USA
}

The 553 tumor suppressor gene product interacts with the p300 transcriptional coactivator that regulates the transactivation of p53-inducible genes. The adenovirus E1A protein has been shown to bind to p300 and inhibit its function. E1A inhibits p53 transactivation and also promotes p53 accumulation by a p300-dependent mechanism. Murine double minute 2 (Mdm2) is a transcriptional target of p53 that binds to p53 and inhibits its transcriptional activity. E1A inhibited $\mathrm{mdm} 2$ transactivation without affecting the expression of p21 ${ }^{\mathrm{WAF1}}$ or Bax, which resulted in high levels of p53 accumulation and apoptosis. Ectopic expression of p300 restored Mdm2 levels and inhibited p53-dependent apoptosis, as did ectopic expression of Mdm2. Thus, p300 is required for $\mathrm{mdm} 2$ induction by $\mathrm{p} 53$ and the subsequent inhibition of p53 stabilization. Inhibition of p300 by E1A results in stabilization of p53 and causes apoptosis. Moreover, E1B 19K or Bcl-2 expression in E1A-transformed cells abrogated p53-dependent apoptosis by restoring $\mathrm{mdm} 2$ transactivation by p53. Hence, p300 regulation of $\mathrm{mdm} 2$ expression controls apoptotic activity of p53, and $19 \mathrm{~K}$ or Bcl-2 bypass E1A inhibition of $\mathrm{p} 300$ transactivation of Mdm2.

[Key Words: p53; M dm2; p300; apoptosis; Bcl-2; E1B 19K; E1A; transcription]

Received December 29, 1997; revised version accepted M ay 4, 1998.

The tumor suppressor p53 gene product is a negative regulator of cellular growth and transformation (Vogelstein and Kinzler 1992; Ko and Prives 1996; Levine 1997; White 1996). M any studies have demonstrated that p53 functions as a transcriptional regulator by sequence-specific DN A binding (El-Deiry et al. 1992; Funk et al . 1992; Pietenpol et al. 1994). The p53 gene product regulates transcription by activation or repression (Ko and Prives 1996). Studies have shown that DN A damage increases p53 levels, which promotes cell cycle arrest allowing DN A repair to occur, or it induces apoptosis, presumably when damage is beyond repair (Ko and Prives 1996; White 1996; Levine 1997). The growth arrest function of p53 is implemented predominantly by transactivation of the cyclin-dependent kinase inhibitor p21/WAF1/CIP1 (El-Deiry et al. 1993) and p53 can induce apoptosis by up-regulating the death-promoting bax gene (M iyashita and Reed 1995). Other transcriptional targets for p53 include GADD45 (Kastan et al. 1992), murine double minute 2 ( $\mathrm{mdm} 2$ ) (Barak et al. 1993; Wu et al. 1993), cyclin G (Okamoto and Beach 1994), and IGF-BP3 (Buckbinder et al. 1995). The DN A-binding ability of p53 appears to be important because the most frequently oc-

${ }^{1}$ Corresponding author.

E-MAIL ewhite@mbcl.rutgers.edu; FAX (732) 235-5795. curring p53 mutations in human tumors are found in this domain (Hollstein et al. 1991; Ko and Prives 1996). Hence, intact p53 transcriptional function is important to maintain genomic integrity.

The mam2 gene was originally cloned because of its amplification in a spontaneously transformed murine BALB/c cell line (Fakharzadeh et al. 1991). The human homolog of $\mathrm{Mdm} 2$ protein was shown to be a negative regulator of p53. $\mathrm{Mdm} 2$ protein inhibits p53-mediated functions of $G_{1}$ arrest and apoptosis (Chen et al. 1996a), most likely by binding to the amino-terminal transactivation domain of p53 (M omand et al. 1992; Oliner et al. 1993). Furthermore, Mdm2 appears to direct p53 degradation via the ubiquitin pathway (Haupt et al. 1997; Kubbutat et al. 1997). The mdm2 promoter contains p53 binding consensus sequences in which p53 binds and positively regulates its expression, creating a negative feedback loop for regulating the activity and levels of p53 (Barak et al. 1993; Haupt et al. 1996; Wu et al. 1993). The functional interdependence of $\mathrm{Mdm} 2$ and p53 was exemplified in studies with knockout mice. Loss of $\mathrm{Mdm} 2$ resulted in early embryonic lethality, which was rescued by deletion of p53 (Donehower et al. 1992; Montes de Oca Luna et al. 1995). Thus, $M d m 2$ is required in vivo for down-modulation of p53 function and perturbation of this regulation can be del eterious to embryonic development. 
The CBP/p300 family members regulate transcription by functioning as transcriptional coactivators. Although the precise mechanism of transcriptional adaptor function is not known, CBP/p300 and an interacting protein, $\mathrm{P} / \mathrm{CAF}$, have been shown to have histone acetyltransferase activity (Bannister and Kouzarides 1996; Ogryzko et al. 1996; Y ang et al. 1996), implicating a role for histone acetylation in transcriptional regulation. These proteins also interact with several transcription factors such as the TAFs (Thut et al. 1995), TBP (A braham et al. 1993), CREB (Chrivia et al. 1993; Kwok et al. 1994), c-Jun/ v-Jun (Bannister and Kouzarides 1995), c-Myb/v-Myb (Dai et al. 1996), c-Fos (Bannister and Kouzarides 1995), and others, which may determine the specificity of the regulation. The p300 family of proteins has been shown recently to bind to p53 and function as coactivators of p53-inducible genes (A vantaggiati et al. 1997; Gu et al. 1997; Lill et al. 1997; Scolnick et al. 1997). The aminoterminal activation domain of p53 interacts directly with the carboxy-terminal of p300 (Gu and Roeder 1997). It has also been shown that p300 can acetylate the carboxy-terminal domain of p53 and that this modification increases the sequence-specific DNA-binding ability of p53 (Gu and Roeder 1997). Thus, acetylation of specific transcription factors may reflect one level of p300 transcriptional regulation.

The adenoviral early region 1 (E1) genes encode for proteins that aid in cellular transformation by activating proliferation and suppressing apoptosis (White 1993; White and Gooding 1994). Expression of the adenoviral E1A gene stimulates cell cycle progression by interacting with and subverting the function of cellular proteins required for normal cell cycle and transcription regulation. ElA interacts with the retinobalstoma $(\mathrm{Rb})$ gene product as well as its family members, p107 and p130 (Dyson and Harlow 1992; Moran 1993; Whyte et al. 1988). E1A al so binds to and sequesters p300 (Moran 1993; Eckner et al. 1994; Y ang et al. 1996). E1A interactions with these celIular proteins are important for transformation as suggested by the fact that E1A mutants that fail to interact with these proteins are incapable of promoting transformation. Expression of E1A alone, however, is insufficient to transform primary baby rat kidney (BRK) cells because cell cycle deregulation by E1A also stimulates p53-dependent apoptosis. Binding of p300 to E1A cosegregates with induction of p53 and stabilization (SanchezPrieto et al. 1995; Chiou and White 1997; Querido et al. 1997). Transcriptional activation of p53 target genes, such as bax (Han et al. 1996), followed by induction of caspase activation implements cell death (Rao and White 1997; Sabbatini et al. 1997). Transcriptional activation of the p53 target gene p21 ${ }^{\text {WAF1 }}$ is also induced, which contributes to implementation of cell cycle arrest by p53, which is not apparent because of cell death (Sabbatini et al. 1995a,b; Han et al. 1996).

E1A-induced cellular transformation is sustained by coexpression of the $\mathrm{Bcl}-2$ adenoviral homolog, E1B 19K or BCl-2 itself, which inhibit E1A-induced, p53-mediated apoptosis. E1B 19K and $\mathrm{BCl}-2$ inhibit apoptosis in part by binding to the death-promoting Bax protein (Han et al.
1996). Thus E1B 19K or Bcl-2 expression inhibits p53mediated apoptosis but not growth arrest (Debbas and White 1993; Chiou et al. 1994b; Sabbatini et al. 1995a; $\mathrm{H}$ an et al. 1996). These co-operative functions between early adenoviral genes stimulating cell cycle progression and inhibiting apoptosis ensures efficient transformation.

We report that p300 is required specifically for transactivation of the $\mathrm{mdm} 2$ gene by $\mathrm{p} 53$ and for regulating p53-mediated apoptosis. Cells expressing E1A were unable to up-regulate $\mathrm{Mdm} 2$, causing stabilization of high levels of p53 that resulted in p53-dependent apoptosis. In contrast, BRK cells expressing c-M yc instead of E1A, upregulated $M d m 2$, causing inhibition of p53 stabilization and inhibition of p53-dependent apoptosis. Thus, the inabilty to down-regulate p53 is associated with apoptosis and may explain the differences between the p53-dependent apoptotic response of E1A versus $M$ yc transformed cells. Furthermore, E1B 19K or Bcl-2 expression restores mdm2 transactivation at the level of mRN A, bypassing the requirement for p300 cotransactivation. Thus the $\mathrm{Bcl}-2$ family members may regulate the specificity of p53-dependent target gene activation and thereby contribute to inhibition of p53-dependent apoptosis.

\section{Results}

Mdm2 expression regulates p53-dependent apoptosis in BRK cells

BRK cells were transformed by a temperature-sensitive p53 (val 135) mutant and either adenovirus E1A (p53A) or C-Myc (LTR.1A). As previously reported, both types of cell lines expressed the temperature-sensitive p53 (val 135) mutant in which p53 is in the wild-type conformation at the permissive temperature of $32^{\circ} \mathrm{C}$ and in the mutant conformation at the nonpermissive temperature of $37.5^{\circ} \mathrm{C}$ (Debbas and White 1993; Sakamuro et al. 1995). There are two striking differences between E1A +tsp53 (val 135)-transformed (p53A) and myc + tsp53 (val 135)-transformed (LTR.1A) cell lines. First, BRK cells expressing E1A undergo massive apoptosis at the permissive temperature (Debbas and White 1993; Chi ou et al. 1994a; Sabbatini et al. 1995a,b), whereas the Myc-expressing cells undergo a wave of apoptosis within the first $24 \mathrm{hr}$ at the permissive temperature but are predominantly resistant to apoptosis (Sakamuro et al. 1995). Second, E1A-expressing cells maintain high levels of p53, whereas p53 levels are low at $32^{\circ} \mathrm{C}$ in Myc-expressing cells (Debbas and White 1993; Sakamuro et al. 1995). Thus, high levels of p53 correlate with augmentation of the apoptotic response in E1A-expressing p53A cells. Because E1A stabilizes p53 (Lowe and Rul ey 1993; Chiou et al. 1994b) and this activity requires that E1A binds to p300 (Chiou and White 1997), this suggests a possible function for sequestration of p300 and induction of p53 levels. Furthermore, recent reports demonstrate the requirement for p300 in p53 transactivation (Gu et al. 1997; Lill et al. 1997; Scolnick et al. 1997) and a role for M dm2 in promoting p53 degradation (Haupt et al. 1997; 
Kubbutat et al. 1997). We therefore investigated the possible role of p300 in the $\mathrm{M} \mathrm{dm} 2$-dependent negati ve-feedback loop and the control of p53-dependent apoptosis.

First, we determined whether the levels of p53-inducible gene products $\mathrm{Mdm} 2, \mathrm{p} 21^{\mathrm{WAF} 1}$, and Bax were affected by the p300-binding protein E1A. Western blot analysis shows that high levels of p53 were stabilized in E1A-transformed cells and not stabilized in Myc-transformed cells at $32^{\circ} \mathrm{C}$ (Fig. 1A) as reported previously
(Debbas and White 1993; Sakamuro et al . 1995). A lower band that may represent a proteolytic cleavage product of p53 was also observed in p53A cells as apoptosis progressed at the permi ssi ve temperature (Fig. 1A). High p53 levels correlated with apoptosis in p53A cells (Fig. 1, C, top, and $\mathrm{D}$, top). Endogenous $\mathrm{Mdm} 2$ protein was initially present but was down-regulated at $32^{\circ} \mathrm{C}$ in p53A cells as shown by Western blot analysis (Fig. 1A) and immunofluorescence (Fig. 1B, top). Western blot analysis of
A
P53 A

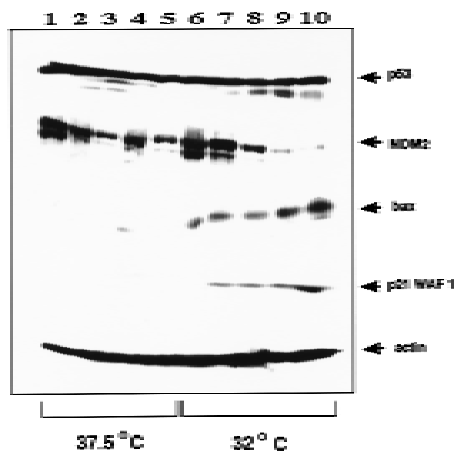

LTR1A

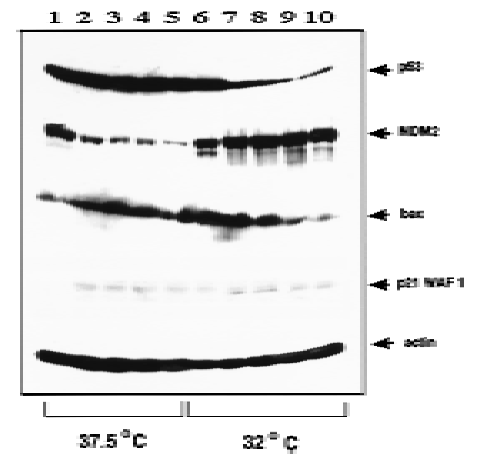

B
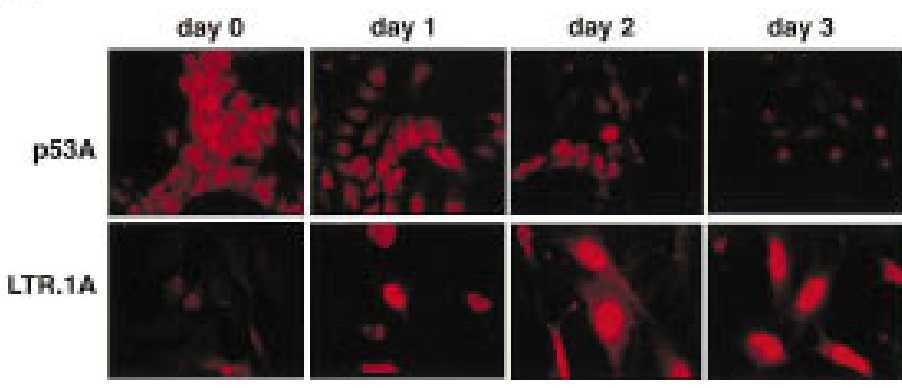

D

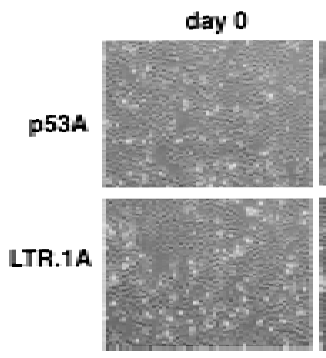

day 1

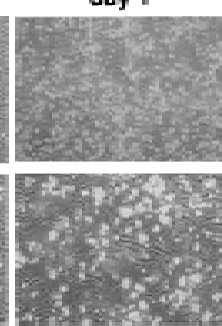

day 2

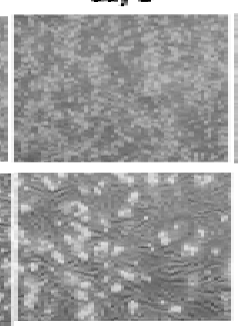

day 3

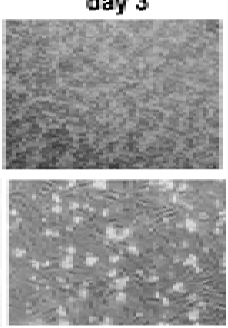

C

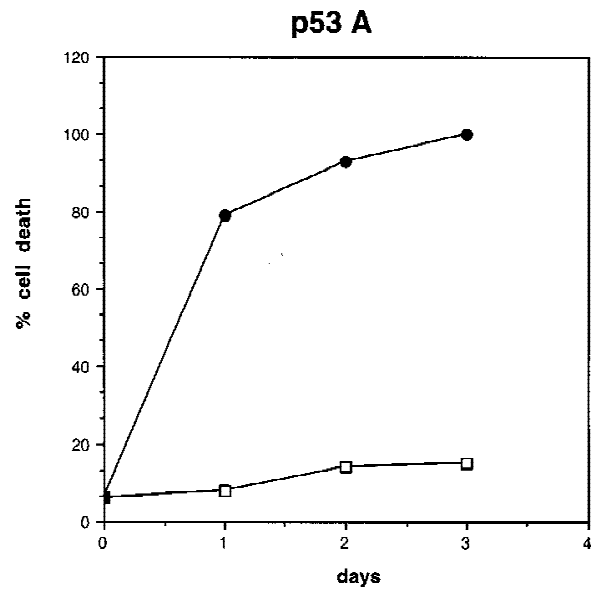

LTR.1A

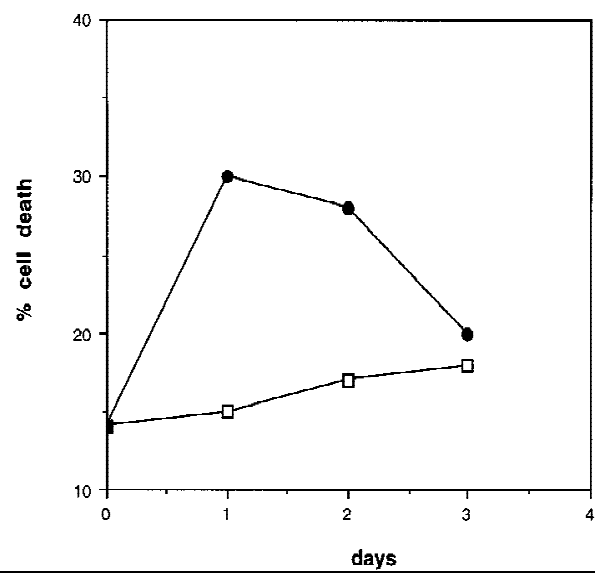

$\mathbf{E}$

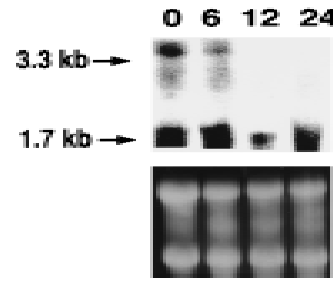

Figure 1. (A) Western blot analysis of p53, Mdm2, Bax, and p21 WAF1 in p53A and LTR.1A cells after incubation at nonpermissive $\left(37.5^{\circ} \mathrm{C}\right.$ ) and permissive $\left(32^{\circ} \mathrm{C}\right.$ ) temperature at day 0 (lanes 1,6$)$, day 1 (lanes 2,7 ), day 2 (lanes 3,8), day 3 (lanes 4,9 ), and day 4 (lanes 5,10 ). (B) Indirect immunofluorescence of $\mathrm{M} \mathrm{dm} 2$ in p53A (top) and LTR.1A (bottom) cells after incubation at $32^{\circ} \mathrm{C}$ from day 0 to day 3. (C) Cell viability by trypan blue staining of p53A and LTR.1A cells at the nonpermissive $\left(37.5^{\circ} \mathrm{C}, \square\right)$ and permissive $\left(32^{\circ} \mathrm{C}, \bullet\right)$ temperature from day 0 to day 3. (D) Analysis of p53A and LTR.1A cells incubated at $32^{\circ} \mathrm{C}$ from day 0 to day 4 by light microscopy to detect apoptotic cells. (E) N orthern blot analysis of $\mathrm{mdm} 2$ expression of p53A cells incubated at $32^{\circ} \mathrm{C}$ for the indicated times. 
Mdm2 in p53A cells at the permissive temperature showed a lower band at $\sim 50 \mathrm{kD}$, recognized specifically by the anti-Mdm2 monoclonal antibody (data not shown). This lower band may represent a cleavage product of Mdm2. However, this band disappeared as cells were incubated at the permi ssive temperature. Our studies did not investi gate $\mathrm{M} \mathrm{dm} 2$ cleavage in apoptosis, however, we cannot rule out the possibility that $\mathrm{Mdm} 2$ cleavage may play a role in the regulation of apoptosis. $\mathrm{Mdm} 2$ down-regulation was surprising because $\mathrm{mdm} 2$ is a p53-regulated gene and suggested that p300 may be necessary for $\mathrm{Mdm} 2$ transactivation by $\mathrm{p} 53$.

In c-M yc-transformed LTR.1A cells, Mdm2 was upregulated and $p 53$ levels were low at $32^{\circ} \mathrm{C}$ (Fig. $1 \mathrm{~A}, \mathrm{~B}$, bottom). Therefore Myc- but not E1A-expressing BRK cells demonstrate p53-dependent induction of $\mathrm{mdm} 2$. Furthermore, high levels of Mdm2 in Myc-transformed BRK cells may have promoted p53 degradation (Fig. 1A). The LTR.1A cells initially undergo apoptosis but rapidly become resistant to p53-mediated cell death at $32^{\circ} \mathrm{C}$ (Fig. $1 C$, bottom, and 1D, bottom), which correlated with the low levels of p53 and up-regulation of Mdm2. Western bl ot analysis also showed an increase in the 50-kD lower band detected specifically by the anti-Mdm2 antibody (data not shown). Hence, the lower band that may represent $\mathrm{Mdm} 2$ cleavage product was also present in cells that were resistant to apoptosis. The decrease in $\mathrm{Mdm} 2$ levels observed in cells maintained at the restrictive temperature may be because of the confluency of the cells. At the restrictive temperature the BRK cell lines are prol iferating and reach confluence in 2-3 days in this assay.

$\mathrm{Mdm} 2$ is only one of many p53-inducible genes that collectively act to modulate the physiological response to p53 induction. Therefore, p21 WAF1 and Bax levels were also examined for transactivation in p53A and LTR.1A cells. In p53A cells, Bax and p21 WAF1 levels were induced at $32^{\circ} \mathrm{C}$ even in the presence of E1A and inhibition of p300 (Fig. 1A) (Sabbatini et al. 1995b; Han et al. 1996). LTR.1A cells down-regulated Bax but up-regulated low levels of $\mathrm{p} 21^{\mathrm{WAF} 1}$ at $32^{\circ} \mathrm{C}$ (Fig. 1A). We do not know why Bax is also present in LTR.1A cells at the restrictive temperature, but this suggests that Bax may require an activation step to induce cell death. Similar results (data not shown) were obtained with independent E1A +tsp53 (val 135)-transformed and c-M yc +tsp53 (val135)-transformed clones (Debbas and White 1993; Sakamuro et al. 1995). These results indicate that E1A and $\mathrm{Myc}$ alter p53-dependent gene expression differentially.

To determine whether the absence of $\mathrm{Mdm} 2$ protein in p53A cells reflected a transcriptional event, we performed Northern bl ot analysis using cytoplasmic RN A extracted from E1A-transformed p53A cells incubated at the permissive temperature for the indicated time intervals (Fig. 1E). Two transcripts (3.3 and $1.7 \mathrm{~kb}$ ) hybridized to an mdm2-specific probe. Both transcripts, particularly the $3.3 \mathrm{~kb}$, were down-regulated to some extent as cells were incubated at $32^{\circ} \mathrm{C}$. The detection of mdm $2 \mathrm{mRN} A$ in p53A cells was difficult because mdm2 expression was very low to begin with and was not induced by wildtype p53. Induction of mdm2 mRNA by p53, however, was observed in BRK cell lines expressing E1B 19K (see below). In contrast, we have previously reported that Bax and p21 WAF1 mRNAs were up-regulated transiently in p53A cells incubated at the permissive temperature within the same time interval analyzed here for $\mathrm{mdm} 2$ mRN A expression (Sabbatini et al. 1995a,b; Han et al. 1996). Attempts to examine mdm 2 mRN A level s at later times failed as the RNA in p53A cells became degraded as most of the cells became apoptotic. Therefore, E1A, although preventing mdm2 expression, did not affect p53's ability to transactivate Bax and p21 WAF1. These results suggest that p300 may be required for $\mathrm{Mdm} 2$ transactivation, but may be dispensable for Bax and p21 $1^{\text {WAFI }}$ regulation.

p300 is required for the up-regulation of $\mathrm{Mdm} 2$ by p53 and inhibition of p53-mediated apoptosis

We next attempted to rescue p53A cells from apoptosis at the permissive temperature by ectopically expressing p300. Vector alone, wild-type p300, and a functional but truncated form of p300 with a deletion of E1A-binding domain (Arany et al. 1994) were transiently transfected in p53A cells. p53-dependent apoptosis was examined at the permissive temperature $48 \mathrm{hr}$ post-transfection. p53A cells transiently expressed the exogenous wildtype p300 and the E1A-binding mutant form of p300, neither of which were detected in mock transfected cells (Fig. 2A,B). The up-regulation of $\mathrm{Mdm} 2$ in p300-transfected cells was not detected by Western blot analysis above endogenous levels (Fig. 2A) because the transfection efficiency was low in transi ent assays. However, the up-regulation of $\mathrm{Mdm} 2$ in both wild-type and E1A-binding mutant of p300 was easily observed in $90 \%$ of transfected cells by indirect immunofluorescence when individual transfected cells were examined (Fig. 2B, arrows). Furthermore, ectopic expression of wild-type and mutant p300 rescued cells from apoptosis as cell viability was elevated as much as $20 \%-40 \%$ above mock-transfected cells (Fig. 2C). The mutant form of p300, which was unable to bind E1A, protected cells better than wildtype p300, presumably because it can evade E1A sequestration. In addition, we determined the percentage of cells with apoptotic morphology that were expressing wild-type p300 ectopically or the E1A-binding mutant of p300 foll owing transient transfection with $24 \mu \mathrm{g}$ of plasmid DNA. Apoptotic morphology was determined by counting cells that were rounded in shape and detaching from the dish. The percentage of cells with apoptotic morphology transiently expressing a control protein, a fragment of the lamin A protein (Rao et al. 1996), compared to p300 and mutant p300 transfected p53A cells at the permissive temperature was determined by indirect immunofluorescence (Fig. 2D). Only 4\%-8\% of the cells expressing wild-type p300 and mutant p300, respectively, have apoptotic morphology compared to $62 \%$ cells expressing the lamin fragment (Fig. 2D). These results 
A
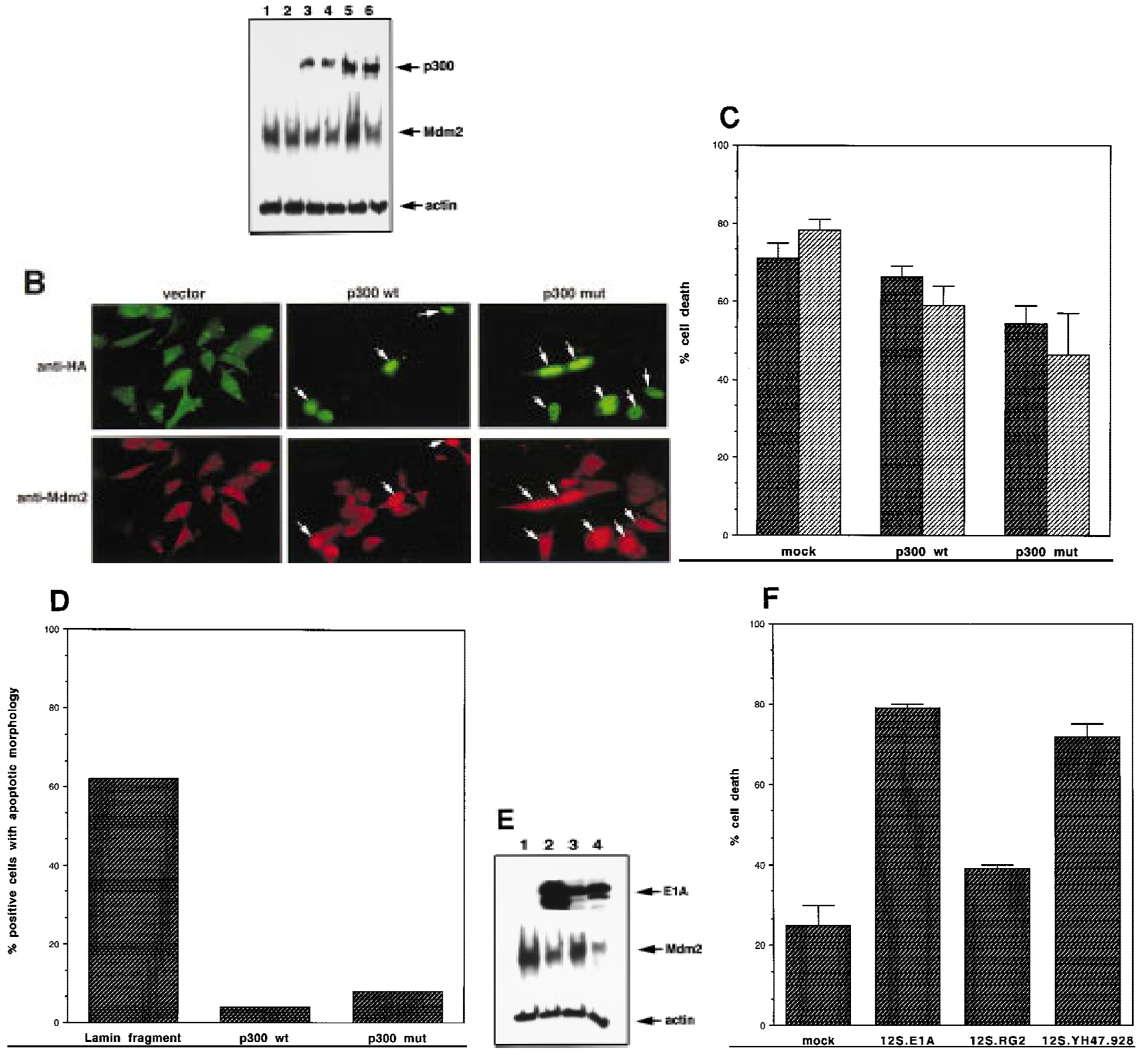

Figure 2. Transient expression of p300 and 12S E1A plasmids in p53A and LTR.1A cells, respectively, reversed its apoptotic phenotype at the permissive temperature. (A) Western blot analysis of ectopically expressed HA-tagged p300, endogenous M dm2, and actin in p53A cells transfected transiently by el ectroporation with pCM V $\beta$ al one (lane 1, $12 \mu$ g; lane 2, $24 \mu g$ ), pCM V $\beta$ p300 (p300 wild-type) (lane 3, $12 \mu \mathrm{g}$; lane 4, $24 \mu \mathrm{g}$ ), or p300 30 (p300 mutant) (lane 5, $12 \mu \mathrm{g}$; lane 6, $24 \mu \mathrm{g}$ ). (B) Indirect immunofluorescence of HA-tagged p300 and endogenous $\mathrm{M} \mathrm{dm} 2$ in p53A cells transfected transiently with $24 \mu \mathrm{g}$ of vector al one, wild-type p300, and mutant p300 (arrows indicate cells with ectopic $\mathrm{p300}$ expression and up-regulation of $\mathrm{M} \mathrm{dm2).} \mathrm{(C)} \mathrm{Cell} \mathrm{viability} \mathrm{as} \mathrm{measured} \mathrm{by} \mathrm{trypan} \mathrm{blue} \mathrm{staining} \mathrm{of} \mathrm{p53A}$ cells transfected transiently with vector al one, wild-type p300, or mutant p300. (Dark hatched bars) $12 \mu \mathrm{g}$; (light hatched bars) $24 \mu \mathrm{g}$. (D) Percentage of apoptotic cells that are positive for ectopic expression of a control lamin fragment, p300 wild-type and p300 mutant determined by cell morphology using indirect immunofluorescence in p53A cells transfected transiently with $24 \mu \mathrm{g}$ of pCEP4-LA(1406). $p C M V \beta p 300$ or $p C M V \beta p 300 \Delta 30$ plasmid DNAs. (E) Western bl ot analysis of E1A, M dm2, and actin in LTR.1A cells transfected transiently with $10 \mu \mathrm{g}$ of vector al one (lane 1), 12S E1A (lane 2), 12S.RG2 (lane 3), or 12S.YH47.928 (lane 4). (F) Cell viability measured by trypan blue exclusion of LTR.1A cells transfected transiently with vector al one, 12S E1A, 12S.RG2, or 12S.YH47.928.

reaffirm that expression of wild-type p300 or the E1Abinding p300 mutant is sufficient to rescue cells from p53-mediated apoptosis.

To determine whether LTR.1A cells can be made sus- ceptible to p53-mediated death, we transiently transfected wild-type E1A (12S E1A) into these cells. Transient expression of 12S E1A in LTR.1A cells (Fig. 2E) promoted apoptosis at the permissive temperature (Fig. 
2F). In addition, $M d m 2$ levels were down-regulated in cells transfected with 12S E1A as detected by Western bl ot analysis (Fig. 2E). Because E1A can also bind to Rb, we transiently transfected LTR.1A cells with 12S E1A mutant (12S.RG2) that is unable to bind to p300 but retains it ability to bind to $\mathrm{Rb}$, and a $12 \mathrm{~S} E 1 \mathrm{~A}$ mutant (12S.Y H47.928) that binds to p300 but not to Rb (Wang et al. 1992), and examined p53-dependent apoptosis at the permissive temperature. Cells transfected with 12S.RG2 did not down-regulate $\mathrm{M} \mathrm{dm} 2$ (Fig. $2 \mathrm{E}$ ) and were resistant to p53-dependent apoptosis (Fig. 2F). In contrast, cells transfected with 12S.YH47.928 down-regulated Mdm2 (Fig. 2E) and were susceptible to p53-dependent apoptosis at the permi ssi ve temperature (Fig. $2 \mathrm{~F}$ ). These results suggest that the ability of E1A to bind to p300 and inhibit Mdm2 induction correlates with E1A-mediated, p53-dependent apoptosis.

\section{Overexpression of $\mathrm{Mdm} 2$ inhibits p53-mediated apoptosis}

To determine whether $\mathrm{Mdm} 2$ expression can bypass the requirement for $\mathrm{p} 300$ cotransactivation and rescue p53A cells from p53-mediated death, we transiently transfected p53A cells with expression plasmids encoding wild-type $\mathrm{Mdm} 2$ and a truncated form of $\mathrm{Mdm} 2$ lacking the amino-terminal p53-binding domain (Haupt et al. 1997). T ransi ent overexpression of wild-type and mutant Mdm2 were detected by Western blot analysis in p53A cells (Fig. 3A). T ransi ent transfection of cells with 5 or 10 $\mu \mathrm{g}$ wild-type $\mathrm{Mdm} 2$ rescued cells from p53-dependent apoptosis at the permissive temperature (Fig. 3B). The truncated form of $\mathrm{Mdm} 2$ rescued cells from apoptosis less efficiently than the wild-type protein (Fig. 3B), presumably because it was not able to bind to p53 and pro-

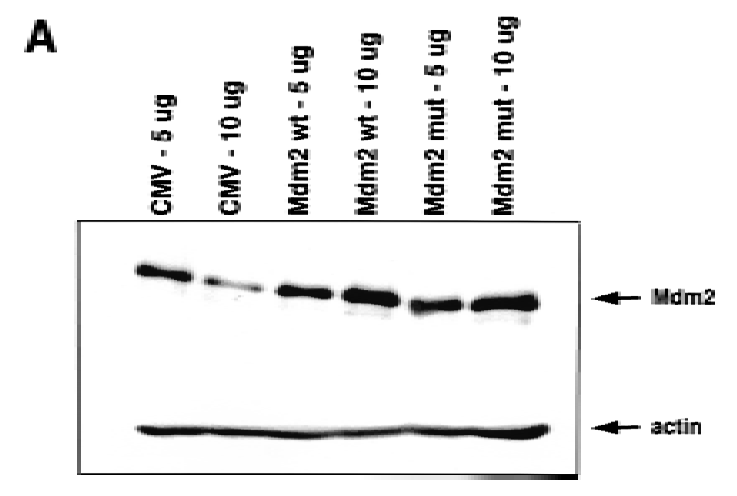

B
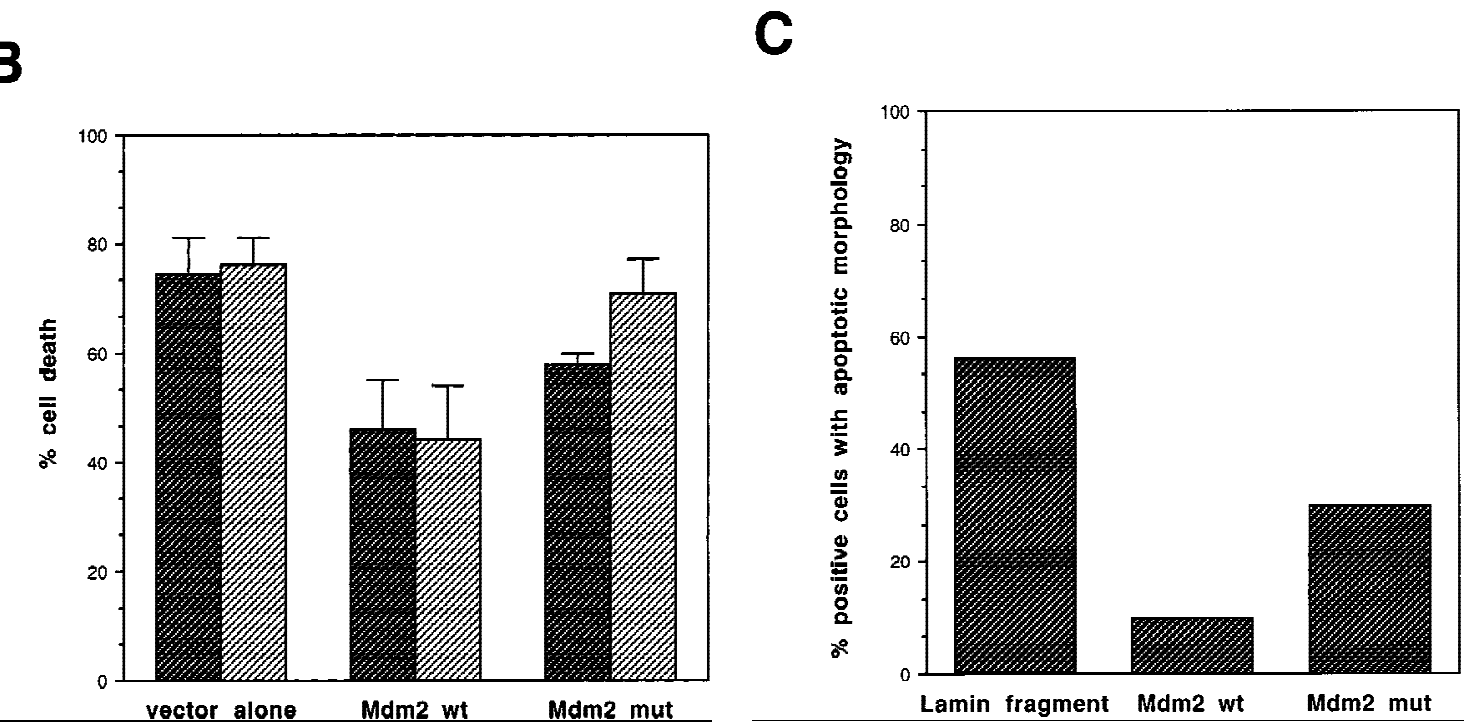

Figure 3. Expression of $M d m 2$ rescues p53A cells from apoptosis at the permissive temperature. (A) Western blot analysis of p53A cells transfected transiently with 5 and $10 \mu \mathrm{g}$ of $\mathrm{pCMV}$ vector alone, $\mathrm{mdm} 2$ wild-type (pCOC-X ${ }_{2}$, or mdm2 mutant (pCOC- $\Delta \mathrm{XM}$ ) plasmid DN As. (B) Cell viability assessed by trypan blue staining of p53A cells transfected transiently with mdm2 expression plasmids incubated at $32^{\circ} \mathrm{C}$. (Dark hatched bars) $5 \mu \mathrm{g}$; (light hatched bars) $10 \mu \mathrm{g}$. (C) Percentage of apoptotic cells that were positive for ectopic expression of a control lamin fragment, $\mathrm{Mdm} 2$ wild-type, and $\mathrm{Mdm} 2$ mutant determined by cell morphology using indirect immunofluorescence in p53A cells transfected transiently with $10 \mu \mathrm{g}$ of pCEP4-LA (1-406), pCOC-X 2 , or pCOC- $\Delta$ XM plasmid DNAs. 
mote its degradation. Furthermore, we examined the cell morphology of p53A cells expressing a wild-type and mutant Mdm2 plasmid DNA as compared to the morphology of cells expressing a control lamin fragment incubated at the permi ssi ve temperature using indirect immunofluorescence (Fig. 3C). The percentage of apoptotic cells expressing wild-type and mutant $\mathrm{Mdm} 2$ was only $10 \%$ and $30 \%$, respectively, as compared to $56 \%$ apoptosis in cells expressing the control lamin fragment (Fig. 3C). The Mdm2 mutant, however, possessed greater apoptosis-suppressing activity than the control Iamin fragment, which may indicate that $\mathrm{Mdm} 2$ can suppress apoptosis by a mechanism independent of p53 binding. These results demonstrate that overexpression of $\mathrm{Mdm} 2$ can rescue E1A-expressing cells from p53-mediated apoptosis by either promoting p53 degradation or by inhibiting its activity by direct interaction.

E1B $19 \mathrm{~K}$ or $\mathrm{Bcl}-2$ can bypass $\mathrm{E} 1 \mathrm{~A}$ inhibition of $\mathrm{p} 300$ and restore $\mathrm{mdm} 2$ transactivation

Another mechanism for suppressing p53-dependent apoptosis is through expression of Bcl-2 or E1B 19K, which function in part by binding to Bax and inactivating its pro-apoptotic function. To test if Bcl-2 or E1B 19K could also function to suppress apoptosis by influencing p53 target gene expression, we examined p53-inducible gene products, $\mathrm{Mdm} 2, \mathrm{p} 21^{\mathrm{WAF} 1}$, and Bax, in p53A cells stably expressing adenovirus E1B 19K (19K1) or its human homolog Bcl-2 (4B).

As reported previously, the expression of $19 \mathrm{~K}$ or $\mathrm{Bcl}-2$ abrogates p53-dependent apoptosis at $32^{\circ} \mathrm{C}$ (Chiou et al. 1994a; Sabbatini et al. 1995a; Han et al. 1996). Western blot analysis indicated that p21 ${ }^{\mathrm{WAF} 1}$ and Bax levels increased at $32^{\circ} \mathrm{C}$ regardl ess of whether or not $19 \mathrm{~K}$ or $\mathrm{BCl}-2$ were expressed and the levels of p53 remained high (Fig. $4 \mathrm{~A}$ ). However, the presence of $19 \mathrm{~K}$ or $\mathrm{Bcl}-2$ dramatically up-regulated $\mathrm{Mdm} 2$ levels, whereas the control E1A + tsp53 (val 135)-transformed p53A cells transfected with vector alone (p53An1) down-regulated $M d m 2$ as expected (Fig. 4A). This suggested that E1B 19K or Bcl-2 could restore p53-dependent $\mathrm{mdm} 2$ expression in p53A cells.

To determine whether the expression of E1B 19K or $\mathrm{BCl}-2$ was sufficient for up-regulation of $\mathrm{M} \mathrm{dm} 2$ level s, we transiently transfected $19 \mathrm{~K}$ or $\mathrm{Bcl}-2$ in p53An1 cells and examined $\mathrm{Mdm} 2$ levels at $32^{\circ} \mathrm{C}$. Western blot analysis (Fig. 4B) and indirect immunofluorescence (data not shown) indicated that $M d m 2$ levels were up-regulated when either $19 \mathrm{~K}$ or $\mathrm{Bcl}-2$ was expressed transi ently.

To determine whether the expression of E1B 19K upregulates $M d m 2$ at the transcriptional level, we performed N orthern blot analysis using cytoplasmic RN A from cells expressing E1B $19 \mathrm{~K}(19 \mathrm{~K} 1)$ incubated at $32^{\circ} \mathrm{C}$ for the indicated time intervals (Fig. 4C). As shown in Fig. 4C, mdm2 mRN A expression was up-regulated after $48 \mathrm{hr}$ incubation at permissive temperature. This suggested that $\mathrm{E} 1 \mathrm{~B} 19 \mathrm{~K}$ and $\mathrm{Bcl}-2$ may restore $\mathrm{mdm} 2$ transactivation by $\mathrm{p} 53$, which would otherwise be inhibited

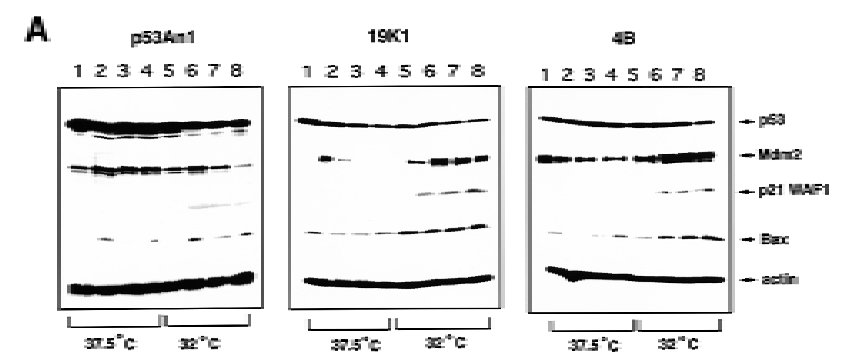

B
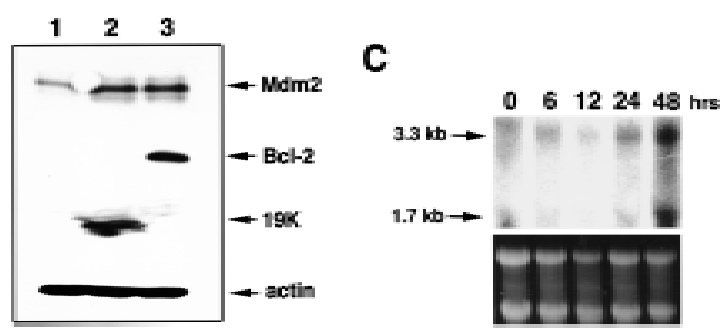

Figure 4. (A) Western blot analysis of $p 53, M d m 2$, bax, and p21 WAF1 in p53A cells stably expressing pSVneo (p53 An1), E1B 19K (19K1), or Bcl-2 (4B). p53An1, 19K1, and 4B cell lines were made as described previously (Sabbatini et al. 1995a). Cell lysates were made after incubating cells at 37.5 or $32^{\circ} \mathrm{C}$ during day 0 (lanes 1,5), day 1 (lanes 2,6), day 2 (lanes 3,7), and day 3 (lanes 4,8). (B) Western blot analysis of M dm2, Bcl-2, E1B 19K, and actin in p53An1 cells transfected transiently with pCDNA3 al one (lane 1), pCM V194K (lane 2), and pCDN A 3myc-taggedbcl-2 (lane 3). (C) $\mathrm{N}$ orthern blot analysis of $\mathrm{mdm} 2$ expression using $30 \mu \mathrm{g}$ of cytoplasmic RN A of $19 \mathrm{~K} 1$ cells incubated at $32^{\circ} \mathrm{C}$ for the indicated time intervals.

by E1A binding to p300. In addition, previous studies have shown that Bax and $\mathrm{p} 21^{\mathrm{WAF} 1} \mathrm{mRNA}$ and protein were also up-regulated in $19 \mathrm{~K} 1$ cells incubated at the permissive temperature (Sabbatini et al . 1995a,b; Han et al. 1996). Therefore the presence of $19 \mathrm{~K}$ di d not affect the expression of Bax or p21 WAF1, however, E1B 19K can directly bind to Bax and inhibit its function (Han et al. 1996). E1B 19K and Bcl-2 have been shown to relieve transcriptional repression by E1A and p53, which may be responsible for inhibition of apoptosis (Shen and Shenk 1994; Sabbatini et al. 1995a; Murphy et al. 1996) and Mdm2 may be a physiological target of this activity.

\section{Discussion}

E1A +tsp53 (val135)-transformed p53A cells were unable to transactivate $\mathrm{mdm} 2$ as a result of E1A inhibition of p300, indicating that p53 requires p300 to transactivate $\mathrm{mdm} 2$ (Fig 5). Furthermore, low Mdm2 levels in p53A cells relieve the negative-feedback regulation of p53 resulting in high p53 accumulation leading to apoptosis. In contrast, p300 function is intact and able to transactivate $\mathrm{mdm} 2$ with p53 in c-M yc +tsp53 (val 135)transformed LTR.1A cells (Fig. 5). Up-regulation of mdm2 inhibits p53 function and promotes p53 degradation (Haupt et al. 1997; Kubbutat et al. 1997), which in turn inhibits p53-mediated cell death resulting in growth 
p53A

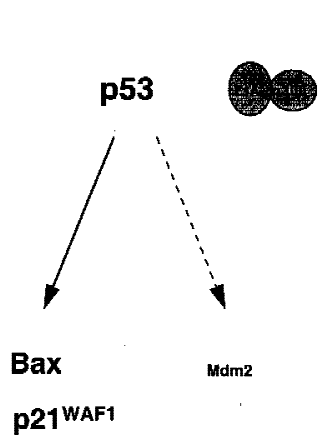

apoptosis control the biological response to p53 such that lower levels of p53 induce growth arrest, whereas higher levels induce apoptosis (Chen et al. 1996b). Therefore, we can conclude that p300 regulation of $\mathrm{Mdm} 2$ levels determines whether the physiological response to p53 is growth arrest or apoptosis. Curiously, the expression of the $19 \mathrm{~K}$ or $\mathrm{Bcl}-2$ proteins in p53A cells $(19 \mathrm{~K} 1,4 \mathrm{~B})$ bypasses the requirement for p300 in $\mathrm{mdm} 2$ transactivation (Fig. 5). Thus, prosurvival members of the Bcl-2 family can inhibit p53-dependent apoptosis by restoring the capacity of p53 to transactivate $\mathrm{mdm} 2$.

Interestingly, p300 cotransactivation is not required for the other p53-inducible genes, Bax and p21 WAF1. It has been reported previously that E1A inhibits p53-mediated transactivation using promoter reporter assays (Steegenga et al. 1996). Our studies, however, demonstrate that E1A specifically inhibits endogenous mdm2 transactivation and not other p53-inducible genes such as bax and $\mathrm{p} 21^{\mathrm{WAF} 1}$. p300/CBP functions by interacting not only with p53, but al so with other factors such as the TAFs (Thut et al. 1995), TBP (A braham et al. 1993), CREB (Chrivia et al. 1993; Kwok et al. 1994), c-Jun/v-Jun (Bannister and Kouzarides 1995), c-Myb/V-M yb (Dai et al. 1996), c-Fos (Bannister and Kouzarides 1995), and others. p300 binding to p53 alone may not regulate the specificity of cotransactivation. However, as numerous other protein interactions with p300 occur, this may determine the specificity of transactivation, accounting for differential regulation of p53-inducible genes by $\mathrm{p} 300$.

p300/CBP transcriptional coactivators have been shown to have histone acetyl transferase activity, which can modify chromatin structure and enhance gene expression (Bannister and Kouzarides 1996; Ogryzko et al. 1996). Recently, p300 has been shown to acetylate p53 itself (Gu and Roeder 1997). The acetylation of p53 increases the binding activity of p53 to specific consensus sequences. In vivo, this activity may be required for facilitating p53 tetramer interactions with the DN A template, thereby promoting mdm2 transactivation. How- ever, acetylation of p53 by p300 may not be the only regulatory mechanism to control transactivation of p53inducible genes. Gene transactivation may also depend on interactions with activators as well as coactivators at the promoter site to initiate transcription. Hence, different levels of regulation may play a role in transactivation of p53-inducible genes.

Mutations that inactivate p300 have been described in colorectal and gastric carcinomas (M uraoka et al. 1996), which may suggest that p300 functions as a negative regulator of cell growth. Misense mutations of p300, coupled to the deletion of the second allele of the gene, was observed in these carcinomas (Muraoka et al . 1996). Gene mutations were found in the $\mathrm{Cys} / \mathrm{His}$-rich regions of p300, which are known to play an important role in p300 function. These observations suggests that inactivation of p300 may play a role in the development of carcinomas. E1A inhibition of p300 transactivation may be one mechanism whereby this viral protein promotes cellular transformation. Interestingly, E1A binds Cys/ His-rich region 3 thereby inactivating p300's function (Eckner et al. 1994). Moreover, p300 inactivation may render cells susceptible to agents that induce p53-mediated cell death such as UV and ionizing radiation. It is intriguing to speculate that acetyltransferase inhibitors specific for $\mathrm{p} 300$ may be used in cells that do not respond to chemotherapy regardless of having wild-type p53.

Finally, E1B $19 \mathrm{~K}$ and $\mathrm{BCl}-2$ can bypass E1A inhibition of p300 function and restore mdm2 transactivation, thereby inhibiting p53-dependent apoptosis. The upregulation of mdm2 expression by $\mathrm{E} 1 \mathrm{~B} 19 \mathrm{~K}$ and $\mathrm{Bcl}-2$ may occur by alleviating the repressive function of adenovirus E1A protein caused by p300 inhibition. These results suggest that members of the anti-apoptotic family may promote survival by bypassing the requirement for p300 function. Both $\mathrm{E} 1 \mathrm{~B} 19 \mathrm{~K}$ and $\mathrm{BCl}-2$ have been shown to relieve transcriptional repression by E1A and p53 (Y oshida et al. 1987; Shen and Shenk 1994; Sabbatini et al. 1995a). In addition, E1B 19K can block repression by E1A caused by p300 inhibition (Yoshida et al. 1987; 
Stein et al. 1991; Lee et al. 1995). We cannot rule out the possibility that E1B $19 \mathrm{~K}$ and $\mathrm{Bcl}-2$ might up-regulate a p300-like activity that can then co-operate with p53 to transactivate the mdm2 gene. Hence, E1B 19K and Bcl-2 may promote survival, not only by binding and inhibiting Bax, but also by relieving transcriptional repression or by enhancing transcription.

\section{Materials and methods}

\section{Cells and culture conditions}

Primary Fisher BRK cells were prepared from 6-day-old baby rats and cultured in Dulbecco's modified Eagle medium (DMEM) with $10 \%$ fetal bovine serum as described previously (White et al. 1991). Plasmids were transfected by electroporation, and cells were maintained in DMEM with $10 \%$ fetal bovine serum. The transformed BRK cell line, p53A, was derived from transfection of pCMVE1A and pLTRcGval 135 plasmids (Debbas and White 1993). The $19 K 1$ and $4 \mathrm{~B}$ cell lines were derived from transfecting pCM V19K and pSVBCl-2, respectively, and a neomycin-resistance plasmid, pSVneo, by electroporation (Debbas and White 1993; Chiou et al. 1994a; Sabbatini et al. 1995a). Control cell line p53An1 was derived from p53A cells containing only the neomycin-resistance plasmid (Debbas and White 1993). The LTR.1A cells were generated by transfecting primary BRK cells with $10 \mu \mathrm{g}$ of LTR H-myc, which expresses human c-Myc, and pLTRcGval 135 as described previously (Sakamuro et al. 1995).

\section{Antibodies}

SM P14, a mouse monoclonal anti-M dm2 antibody (Santa Cruz Bi otechnol ogy, Santa Cruz, CA) was used at 1:1000 (Western) or 1:100 (immunofluorescence) to detect Mdm2. PAb248, a murine-specific anti-p53 mouse monoclonal antibody which was kindly provided by $A$. Levine was used at 1:5000 to detect p53. Mouse monoclonal anti-p21 WAF1 (Ab-4, Calbiochem, San Diego, CA ) was used at 1:50 di lution to detect p21 WAF1. A rabbit polyclonal anti-Bax (P-19, Santa Cruz) was used at 1:100 to detect Bax and a mouse monoclonal anti-actin antibody (Amersham) was used at 1:1000 dilution to detect actin. Anti-HA mouse monoclonal antibody (Babco, Richmond, CA) at 1:1000 dilution was used to detect ectopically expressed p300 and a mouse monoclonal anti-E1A antibody M 73 (Calbiochem) was used at 1:1000 dilution to detect E1A. A monoclonal anti-myc antibody (Calbiochem) was used at 1:1000 dilution to detect myc-tagged proteins, Bcl-2, and lamin mutant. A polyclonal anti-E1B 19K antibody was used at $1: 10,000$ to detect transiently expressed E1B 19K.

\section{Cell viability and morphology}

Cell viability was measured by trypan blue staining. Cells were trypsinized, centrifuged, resuspended in PBS, and counted using a hemocytometer after diluting in trypan blue. A poptotic morphology was assessed by scoring for cells that are positive by fluorescence mi croscopy and are rounded and nonadherent. Cell morphology was al so documented by photography at $100 \times$ magnification on a $\mathrm{Nikon}$ phase-contrast microscope and camera using Kodak film.

\section{Western blot analysis}

Cells were incubated at $37.5^{\circ} \mathrm{C}$ and $32^{\circ} \mathrm{C}$ for various time intervals prior to lysing in buffer containing $4 \%$ SDS and $5 \% \beta-$ mercaptoethanol. Equal amounts of protein (20-30 $\mu \mathrm{g})$ were el ectrophoresed on 7.5\%-12\% SDS-PAGE gels and transferred to PVDF membranes. Membranes were blocked for $15 \mathrm{~min}$ at room temperature in 5\% nonfat Carnation dry milk in PBS containing $0.1 \%$ Tween 20 (PBST). Membranes were incubated with primary antibody followed by washes in PBST and then incubated with horseradish peroxidase (HRP)-conjugated sheep anti-mouse IgG or donkey anti-rabbit IgG monoclonal antibody at 1:2000 dilution. After several washes, blots were developed using the ECL chemiluminescence detection kit according to manufacturer's recommendations (Amersham Life Sciences, Arlington Heights, IL).

\section{Indirect immunofluorescence and microscopy}

Cells were fixed in cold methanol prior to incubation with primary antibodies. Subsequent to washes in PBS, cells were incubated with rhodamine-conjugated goat anti-mouse antibody or fluorescein-conjugated goat anti-rabbit antibody. Cells were then washed, mounted, and analyzed by fluorescence microscopy using a $\mathrm{Nikon} \mathrm{FXA} \mathrm{epifluorescence} \mathrm{microscope.}$

\section{Northern blot analysis}

Cytoplasmic RN A was extracted from p53A and 19K1 cells using the N P-40 lysis protocol as described previously (M uraoka et al. 1996). N orthern blots were done by loading $30 \mu \mathrm{g}$ of cytoplasmic RNA on a formaldehyde gel and blotted as described previously (Muraoka et al. 1996) using Hybond-N membranes (A mersham) for transfer. The membrane was hybridized with a random-primed labeled murine mdm2-specific probe in ExpressHyb Hybridization solution (CloneT ech, Palo Alto, CA) at $65^{\circ} \mathrm{C}$. Blots were washed in $0.1 \times$ SSC and $0.1 \%$ SDS at $50^{\circ} \mathrm{C}$ and exposed to film for 2 days.

\section{Transient transfections}

The indicated amount of plasmid DN A was transfected by electroporation. After transfection, cells were incubated at $37.5^{\circ} \mathrm{C}$ for $24 \mathrm{hr}$ to recover, and were then shifted to $32^{\circ} \mathrm{C}$ for $24 \mathrm{hr}$ before analysis for viability by trypan blue staining and apoptotic morphology. For p300 transfections, p53A cells were electroporated with 12 or $24 \mu \mathrm{g}$ of $\mathrm{pCMV} \beta$ al one, $\mathrm{pCMV} \beta \mathrm{p} 300$, or pCMVp300 330 mutant (deletion in E1A-interacting domain) (Arany et al. 1994). For transient expression of E1A proteins, LTR.1A cells were electroporated with $10 \mu \mathrm{g}$ of $\mathrm{pCMV} \beta$ alone, pCMV12SE1A, pCM V12S.RG2, or pCMV12S.YH47.928 (Wang et al. 1992). For $M d m 2$ transient expression, p53A cells were electroporated with 5-10 $\mu \mathrm{g}$ of $\mathrm{pCMV} \beta$ alone, $\mathrm{pCOC}-\mathrm{X}_{2}$ (wildtype $\mathrm{Mdm} 2$ ), and $\mathrm{pCOC}-\Delta \mathrm{XM}$ (mutant $\mathrm{Mdm} 2$ with deletion of the amino-terminal p53-binding domain) (Haupt et al. 1997). p53A cells were transfected transiently with $10 \mu \mathrm{g}$ of pCEP4myc-LA(1-406) by electroporation to detect transient expression of a lamin fragment as a control protein (Rao et al. 1996). Transient expression of $\mathrm{BCl}-2$ and $\mathrm{E} 1 \mathrm{~B}$ 19K was achieved by electroporating $10 \mu \mathrm{g}$ of pCDNA3-Bcl-2 and pCMV19K plasmids into p53A cells.

\section{Acknowledgments}

We thank M oshe Oren for providing the $\mathrm{mdm} 2$ expression plasmids, Steve Grossman for the p300 expression plasmids, Elizabeth Moran for E1A mutant expression plasmids, and Arnold Levine for providing murine-specific anti-p53 antibody. This work was supported by $\mathrm{N}$ ational Institutes of Heal th grant CA60088 to E.W. 
The publication costs of this article were defrayed in part by payment of page charges. This article must therefore be hereby marked "advertisement" in accordance with 18 USC section 1734 solely to indicate this fact.

\section{References}

Abraham, S.E., S. Lobo, P. Yaciuk, H.G. Wang, and E. Moran. 1993. p300, and p300-associated proteins, are components of TATA-binding protein (TBP) complexes. Oncogene 8: 16391647.

Arany, Z., W. Sellers, D. Livingston, and R. Eckner. 1994. E1Aassociated p300 and CREB-associated CBP belong to a conserved family of coactivators. Cell 77: 799-800.

Avantaggiati, M.L., V. Ogryzko, K. Gardner, A. Giordano, A.S. Levine, and K. Kelly. 1997. Recruitment of p300-CBP in p53dependent signal pathways. Cell 89: 1175-1184.

Bannister, A.J. and T. Kouzarides. 1995. CBP-induced stimulation of c-Fos activity is abrogated by E1A. EMBO J. 14: 47584762.

- - - 1996. The CBP coactivator is a histone acetyltransferase. Nature 384: 641-643.

Barak, Y., T. Juven, R. Haffner, and M. Oren. 1993. mdm2 expression is induced by wild type p53 activity. EMBO J. 12: 461-468.

Buckbinder, L., R. Talbott, S. Velasco-Miguel, I. Takenaka, B. Faha, B.R. Seizinger, and N. Kley. 1995. Induction of the growth inhibitor IGF-binding protein 3 by p53. Nature 377: 646-649.

Chen, J., X. Wu, J. Lin, and A.J. Levine. 1996a. mdm-2 inhibits the $\mathrm{G} 1$ arrest and apoptosis functions of the p53 tumor suppressor protein. Mol. Cell. Biol. 16: 2445-2452.

Chen, X., L.J. Ko, L. Jayaraman, and C. Prives. 1996b. p53 levels, functional domains, and DN A damage determine the extent of the apoptotic response of tumor cells. Genes \& Dev. 10: 2438-2451.

Chiou, S.-K. and E. White. 1997. p300 binding by E1A cosegregates with p53 induction but is dispensable for apoptosis. J. Virol. 71: 3515-3525.

Chiou, S.-K., L. Rao, and E. White. 1994a. Bcl-2 blocks p53dependent apoptosis. Mol. Cell. Biol. 14: 2556-2563.

Chiou, S.-K., C.C. Tseng, L. Rao, and E. White. 1994b. Functional complementation of the adenovirus E1B 19K protein with $\mathrm{Bcl}-2$ in the inhibition of apoptosis in infected cells. J. Virol. 68: 6553-6566.

Chrivia, J.C., R.P. Kwok, N. Lamb, M. Hagiwara, M.R. Montminy, and R.H. Goodman. 1993. Phosphorylated CREB binds specifically to the nuclear protein CBP. Nature 365: 855-859.

Dai, P., H. Akimaru, Y. Tanaka, D.X. Hou, T. Yasukawa, C. Kanei-Ishii, T. Takahashi, and S. Ishii. 1996. CBP as a transcriptional coactivator of c-M yb. Genes \& Dev. 10: 528-540.

Debbas, M. and E. White. 1993. Wild-type p53 mediates apoptosis by E1A which is inhibited by E1B. Genes \& Dev. 7: $546-554$

Donehower, L.A., M. Harvey, B.L. Slagle, M.J. McArthur, C.A. M ontgomery, J.S. Butel, and A. Bradley. 1992. Mice deficient for $\mathrm{p} 53$ are developmentally normal but susceptible to spontaneous tumors. Nature 356: 215-221.

Dyson, N. and E. Harlow. 1992. Adenovirus E1A targets key regulators of cell proliferation. Cancer Surv. 12: 161-195.

Eckner, R., M .E. Ewen, D. N ewsome, M. Gerdes, J.A. DeCaprio, J.B. Lawrence, and D.M. Livingston. 1994. M olecular cloning and functional analysis of the adenovirus E1A-associated 300-kD protein (p300) reveals a protein with properties of a transcription adaptor. Genes \& Dev. 8: 869-884.
El-Deiry, W.S., S.E. Kern, J.A. Pietenpol, K.W. Kinzler, and B. Vogelstein. 1992. Definition of a consensus binding site for p53. Nature Genet. 1: 45-49.

El-Deiry, W.S., T. Tokino, V.E. Velculescu, D.B. Levy, R. Parsons, J.M. Trent, D. Lin, E. Mercer, K.W. Kinzler, and B. Vogelstein. 1993. WAF1, a potential mediator of p53 tumor suppression. Cell 75: 817-825.

Fakharzadeh, S.S., S.P. Trusko, and D.L. George. 1991. Tumorigenic potential associated with enhanced expression of a gene that is amplified in a mouse tumor cell line. EMBO J. 10: 1565-1569.

Funk, W.D., D.T. Pak, R.H. Karas, W.E. Wright, and J.W. Shay. 1992. A transcriptionally active DNA-binding site for human p53 protein complexes. Mol. Cell. Biol. 12: 2866-2871.

Gu, W. and R.G. Roeder. 1997. Activation of p53 sequence specific DN A binding by acetylation of the p53 C-terminal domain. Cell 90: 595-606.

Gu, W., X.-L. Shi, and R.G. Roeder. 1997. Synergistic activation of transcription by CBP and p53. Nature 387: 819-823.

Han, J., P. Sabbatini, D. Perez, L. Rao, D. Modha, and E. White. 1996. The E1B 19K protein blocks apoptosis by interacting with and inhibiting the p53-inducible and death-promoting Bax protein. Genes \& Dev. 10: 461-477.

Haupt, Y., Y. Barak, and M. Oren. 1996. Cell type-specific inhibition of p53-mediated apoptosis by mdm2. EMBO J. 15: 1596-1606.

Haupt, Y., R. Maya, A. Kazaz, and M. Oren. 1997. Mdm2 promotes the rapid degradation of p53. Nature 387: 296-299.

Hollstein, M., D. Sidransky, B. Vogelstein, and C. Harris. 1991. p53 mutations in human cancers. Science 253: 49-53.

Kastan, M.B., Q. Zhan, W.S. El-Deiry, F. Carrier, T. Jacks, W.V. Wal sh, B.S. Plunkett, B. Vogelstein, and A.J. Fornace. 1992. A mammalian cell cycle checkpoint pathway utilizing p53 and GADD45 is defective in ataxia-telangiectasia. Cell 13: 587597.

Ko, L.J. and C. Prives. 1996. p53: Puzzle and paradigm. Genes \& Dev. 10: 1054-1072.

Kubbutat, M.H.G., S.N. Jones, and K.H. Vousden. 1997. Regulation of p53 stability by M dm2. Nature 387: 299-303.

Kwok, R.P., J.R. Lundblad, J.C. Chrivia, J.P. Richards, H.P. Bachinger, R.G. Brennan, S.G. Roberts, M.R. Green, and R.H. Goodman. 1994. N uclear protein CBP is a coactivator for the transcription factor CREB. Nature 370: 223-226.

Lee, J.S., K.M. Galvin, R.H. See, R. Eckner, D. Livingston, E. Moran, and Y. Shi. 1995. Relief of YY1 transcriptional re pression by adenovirus E1A is mediated by E1A-associated protein p300. Genes \& Dev. 9: 1188-1198.

Levine, A.J. 1997. p53, the cellular gatekeeper for growth and division. Cell 88: 323-331.

Lill, N.L., S.R. Grossman, D. Ginsberg, J. DeCaprio, and D.M. Livingston. 1997. Binding and modulation of p53 by p300/ CBP coactivators. Nature 387: 823-827.

Lowe, S. and H.E. Ruley. 1993. Stabilization of the p53 tumor suppressor is induced by adenovirus- $5 \mathrm{E} 1 \mathrm{~A}$ and accompanies apoptosis. Genes \& Dev. 7: 535-545.

Miyashita, T. and J.C. Reed. 1995. Tumor suppressor p53 is a direct transcriptional activator of the human bax gene. Cell 80: 293-299.

Momand, J., G.P. Zambetti, D.C. Olson, D. George, and A.J. Levine. 1992. The mdm-2 oncogene product forms a complex with the p53 protein and inhibits p53-mediated transactivation. Cell 69: 1237-1245.

Montes de Oca Luna, R., D.S. Wagner, and G. Lozano. 1995. Rescue of early embryonic lethal ity in mdm2-deficient mice by deletion of p53. Nature 378: 203-206.

Moran, E. 1993. DNA tumor virus transforming proteins and 
the cell cycle. Curr. Opin. Genet. Dev. 3: 63-70.

Muraoka, M., M. Konishi, R. Yanoshita, K. Tanaka, N. Shitara, J.M. Chong, T. Iwama, and M. Miyaki. 1996. p300 gene alterations in colorectal and gastric carcinomas. Oncogene 12: 1565-1569.

Murphy, M., A. Hinman, and A.J. Levine. 1996. Wild-type p53 negatively regulates the expression of a microtubule-associated protein. Genes \& Dev. 10: 2971-2980.

Ogryzko, V.V., R.L. Schiltz, V. Russanova, B.H. Howard, and Y. Nakatani. 1996. The transcriptional coactivators p300 and CBP are histone acetyltransferases. Cell 87: 953-959.

Okamoto, K. and D. Beach. 1994. Cyclin G is a transcriptional target of the p53 tumor suppressor protein. EMBO J. 13: $4816-4822$.

Oliner, J.D., J. Pietenpol, S. Thi agal ingam, J. Gyuris, K.W. Kinzler, and B. Vogelstein. 1993. Oncoprotein MDM 2 conceals the activation domain of tumor suppressor p53. Nature 362: 857-860.

Pietenpol, J.A., T. Tokino, S. Thiagalingam, W.S. El-Deiry, K.W. Kinzler, and B. Vogelstein. 1994. Sequence-specific transcriptional activation is essential for growth suppression by p53. Proc. Natl. Acad. Sci. 91: 1998-2002.

Querido, E.J., J.G. Teodoro, and P.E. Branton. 1997. Accumulation of p53 induced by the adenovirus E1A protein requires regions involved in the stimulation of DNA synthesis. J. Virol. 71: 3526-3533.

Rao, L. and E. White. 1997. Bcl-2 and ICE family of apoptotic regulators: Making a connection. Curr. Opin. Genet. Dev. 7: 52-58.

Rao, L., D. Perez, and E. White. 1996. Lamin proteolysis facilitates nuclear events during apoptosis. J. Cell. Biol. 135: 1441-1455.

Sabbatini, P., S.-K. Chiou, L. Rao, and E. White. 1995a. Modulation of p53-mediated transcription and apoptosis by the adenovirus E1B 19K protein. Mol. Cell. Biol. 15: 1060-1070.

Sabbatini, P., J. Lin, A.J. Levine, and E. White. 1995b. Essential role for p53-mediated transcription in apoptosis but not growth suppression. Genes \& Dev. 9: 2184-2192.

Sabbatini, P., J.H. Han, S.-K. Chiou, D. Nicholson, and E. White. 1997. Interleukin $1 \beta$ converting enzyme-like proteases are essential for p53-mediated transcriptionally dependent apoptosis. Cell Growth Differ. 8: 643-653.

Sakamuro, D., V. Eviner, K.J. Elliot, L. Showe, E. White, and G.C. Prendergast. 1995. c-Myc induces apoptosis in epithelial cells by both p53-dependent and p53-independent mechanisms. Oncogene 11: 2411-2418.

Sanchez-Prieto, R., M. Lleonart, and S. Cajal. 1995. Lack of correlation between p53 protein level and sensitivity to DNAdamaging agents in keratinocytes carrying adenovirus E1A mutants. Oncogene 11: 675-682.

Scolnick, D.M., N.H. Chehab, E.S. Stavridi, M.C. Lien, L. Caruso, E. Moran, S.L. Berger, and T.D. Halazonetis. 1997. CREB-binding protein and p300-CBP-associated factor are transcriptional coactivators of the p53-tumor suppressor protein. Cancer Res. 57: 3693-3696.

Shen, $Y$. and T. Shenk. 1994. Relief of p53 mediated transcriptional repression by the adenovirus E1B 19-kDa protein or the cellular Bcl-2 protein. Proc. Natl. Acad. Sci. 91: 89408944.

Steegenga, W.T., T. van Laar, N. Riteco, A. Mandarino, A. Shvarts, A.J. van der Eb, and A.G. Jochemsen. 1996. Adenovirus E1A proteins inhibit activation of transcription by $p 53$. Mol. Cell Biol. 16: 2101-2109.

Stein, R.W., M. Corrigan, P. Yaciuk, J. Whelan, and E. Moran. 1991. Analysis of E1A-mediated growth regulation functions: Binding of the 300-kilodalton cellular product corre lates with E1A repression function and DNA synthesis-inducing activity. J. Virol. 64: 4421-4427.

Thut, C.J., J.-L. Chen, R. Klemm, and R. Tjian. 1995. p53 transcriptional activation mediated by coactivators $T_{A F} 400$ and $T_{A F} F_{11} 60$. Science 267: 100-104.

Vogelstein, B. and K.W. Kinzler. 1992. p53 Function and dysfunction. Cell 70: 523-526.

Wang, H.-G.H., Y. Rikitake, M.C. Carter, P. Yaciuk, S.E. Abraham, B. Zerler, and E. M oran. 1992. Identification of specific adenovirus E1A $\mathrm{N}$-terminal residues critical to the binding of cellular proteins and the control of cell growth. J. Virol. 67: $476-488$

White, E. 1993. Regulation of apoptosis by the transforming genes of the DNA tumor virus adenovirus. Proc. Soc. Exp. Biol. Med. 204: 30-39.

- - . 1996. Life, death, and the pursuit of apoptosis. Genes \& Dev. 10: 1-15.

White, E. and L.R. Gooding 1994. Regulation of apoptosis by human adenoviruses. In A poptosis: The molecular basis for cell death II. (ed. Tomei, L.D. and F.O. Cope), pp. 111-141. Cold Spring Harbor Laboratory Press, Cold Spring Harbor, NY.

White, E., R. Cipriani, P. Sabbatini, and A. Denton. 1991. The adenovirus E1B 19-Kilodalton protein overcomes the cytotoxicity of E1A proteins. J. Virol. 65: 2968-2978.

Whyte, P., K. Buchkovich, J.M. Horowitz, S.H. Friend, M. Raybuck, R.A. Weinbert, and E. Harlow. 1988. Association between an oncogene and an anti-oncogene: The adenovirus E1A proteins bind to the retinoblastoma gene product. $\mathrm{Na}$ ture 334: 124-129.

Wu, X., J.H. Bayle, D. Olson, and A.J. Levine. 1993. The p53mdm-2 autoregulatory feedback loop. Genes \& Dev. 7: $1126-1132$.

Yang, X.J., V.V. Ogryzko, J. N ishikawa, B.H. Howard, and Y.A Nakatani. 1996. p300/CBP-associated factor that competes with the adenoviral oncoprotein Ela. Nature 382: 319-324.

Y oshida, K., L. Venkatesh, M. Kuppuswamy, and G. Chinnadurai. 1987. Adenovirus transforming 19-kD T antigen has an enhancer dependent trans-activation function and relieves enchancer repression mediated by viral and cellular genes. Genes \& Dev. 1: 645-658. 


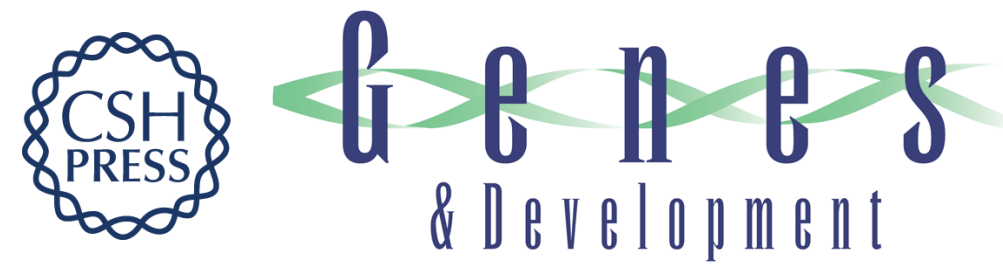

\section{Suppression of the p300-dependent $m d m 2$ negative-feedback loop induces the p53 apoptotic function}

Anju Thomas and Eileen White

Genes Dev. 1998, 12:

Access the most recent version at doi:10.1101/gad.12.13.1975

References This article cites 67 articles, 30 of which can be accessed free at: http://genesdev.cshlp.org/content/12/13/1975.full.html\#ref-list-1

License

Email Alerting

Receive free email alerts when new articles cite this article - sign up in the box at the top Service right corner of the article or click here.

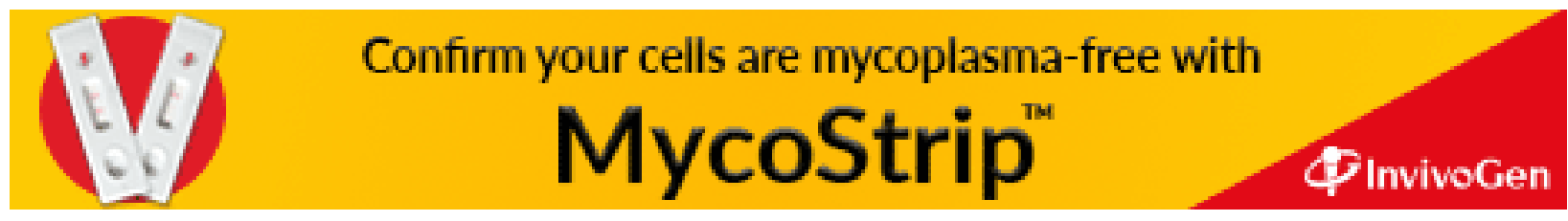

